\title{
Judgment Considerations Policy in Decree of the Court Criminal Statement Based On Criminal Destination
}

\author{
Sulistiyawan Doni Ardiyanto ${ }^{1}$, Eko Soponyono ${ }^{2}$ and Achmad Sulchan ${ }^{3}$
}

\begin{abstract}
Crime theft is usually influenced by several factors, such as livelihoods with neatly organized networks or syndicates or some that do so due to economic pressures that force the offender to commit the crime because in his mind there is no longer a way out other than stealing. The formulation of the problem in this research is What is the judge's judgment policy in deciding cases of theft based on criminal destinations in the Draft Law of the Criminal Code, and in Act No. 48 On judicial power ?. The method of approach used is sociological juridical. This type of research is descriptive method. Source of data used from primary and secondary data. In this case the judge in providing a criminal decision must provide the benefit of the convicted person to undergo his conviction and life after leaving the prison to return to the community again. Because the provision of an unfair criminal will affect the survival of the convicted person. The purpose of punishment is as a judge's consideration in deciding the theft of criminal case which is supported by a juridical element in Article 56 of the Criminal Code Bill, and Act No.48 of 2009 On Judicial Power in Article 5 paragraph (1) and Article 8 paragraph (2).

Keywords: Judge's Considerations, Theft of Crimes, Criminal Purpose.
\end{abstract}

\section{Introduction}

As stated in Article 1 paragraph (3) of the 1945 Constitution of the Republic of Indonesia the result of the amendment confirms that the Indonesian State is a constitutional state. With reference to the provisions of Article 1 paragraph (3) of the 1945 Constitution of the Republic of Indonesia NRI as a result of the amendment, the Indonesian constitution has placed the law in a decisive position in the Indonesian constitutional system.

Society is more familiar with the law as a binding rule and must be obeyed by every individual in the community and if there will be no sanctions for those who break the rules. In law enforcement practices, in the community sanctions have a very important role so that a rule of law is obeyed by the community so that a legal sanction has an essential role so that an objective in establishing a legal rule can be achieved and the expected process of social control in society can be realized properly. ${ }^{4}$ In Indonesia, the institution that has the authority to try and impose sanctions is called a judicial institution, in which there is a state apparatus that exercises the authority to try and decide on a case or problem that occurs in the community that we know as a Judge. The task of the judge is actually a noble task, as explained by Roeslan, about a "struggle for humanity". 5

\footnotetext{
${ }^{1}$ Student of Master of Law, Universitas Islam Sultan Agung Semarang and Indonesian Police, email: pribadiagus10@gmail.com

${ }^{2}$ Lecturer of Faculty of Law, Sultan Agung Islamic University (UNISSULA), Semarang

${ }^{3}$ Lecturer of Faculty of Law, Sultan Agung Islamic University (UNISSULA), Semarang

${ }^{4}$ Haryanto Dwiatmodjo, Penjatuhan Pidana Bersyarat Dalam Kasus Pencurian Kakao, FH Unsoed, Purwokerto, Judicial Journal, Vol.5 No.1, April 2012, p.103

${ }^{5}$ Satjipto rahrdjo, 2006, Perang dibalik Toga Hakim dalam buku : Membedah hukum Progresif, Jakarta: Kompas, p.91
} 
In this statement the responsibility of a judge is seen in carrying out his duties, where they must face inner struggle and turmoil in their souls when they have to make choices that are not easy in making a decision in the case they are tried, and more than that all a judge also must put his ear to the opinion and sense of justice expected by the community. Thus a judge's decision is a reflection of the attitude, morality, reasoning and many other things that are described as the experience of a judge in carrying out his duties and functions. This shows us that in fact the verdict is very cultural relativism so it does not rule out the viewpoints of every judge in a case can be different. ${ }^{6}$

Judges' decisions are legal products issued by judges. Every judge's decision in the form of conviction or imprisonment, acquittal, acquittal is free from all charges. ${ }^{7}$ To issue a decision, the judge needs to consider the severity of the decision. With the basic consideration of judges, judges can be fair in deciding a case. In general, a judge will refer to the principal and additional crimes, as stipulated in Article 10 of the Criminal Code. Where in the criminal sanctions regulated in Article 10 of the Criminal Code, one of them is a prison sentence, where the deprivation of liberty is what is often dropped by the judge in his decision because it is considered more effective and can make the perpetrators of criminal acts become deterrent.

Judges 'consideration of their decisions in general criminal acts, especially in this case theft with weighting when related to criminal individualization can actually be accepted as a natural thing because in dropping the verdict, the judge not only looks at the perpetrators' actions, but looks at the factors other factors involved in it such as the circumstances of the perpetrators in particular, the reasons for actions by weighting or alleviating the punishment, customary law living in the local community, and so forth. But the problem will be different if the criminal disparity occurs without a clear reason. The purpose of punishment is as a principle that is highly considered in the judge's reference to provide decisions in the process of the criminal justice system.

Theft is a criminal offense regulated in Article 362 to Article 367 of the Indonesian Criminal Code (KUHP). A person is said to steal if he takes something that is wholly or partly owned by someone else with the intent to be owned illegally. This theft can occur due to lack of employment, high unemployment, and the price of living necessities increases. Crime theft is a crime that is rife in Indonesia, both in big cities and remote areas. The perpetrators of the crime of theft are usually influenced by several factors, ${ }^{8}$

From the description above shows that the position of the goal of punishment is as one of the important keys in the execution of the crime itself. Because the criminal sentence was handed down not because people committed a crime but with the aim that people did not commit a crime. Not quia peccatum est but ne peccetur. So it is not just giving a verdict of punishment in retaliation to people who commit crimes (absolute theory / retributive theory) but rather to certain goals that are beneficial to the perpetrators of criminal offenses after his conviction (Utilitarian theory).

\footnotetext{
${ }^{6}$ Research Report, " Penerapan dan Penemuan Hukum dalam Putusan Hakim ", Jakarta: Secretariat General of the Indonesian Republic's Judicial Commission, 2011, p. 7-8.

${ }^{7}$ Wirjono Prodjodikoro, 2008, Tindak Tindak Pidana Tertentu Di Indonesia, Bandung: Refika Aditama, p.280.

${ }^{8}$ Chainur Arasjid, 2000, Dasar-Dasar Ilmu Hukum, Jakarta: Sinar Grafika, p. 133.
} 
Based on the description on the background of the problem above, then the problem formulation can be formed as follows:

What is the judge's consideration policy in deciding cases of theft that should be based on the purpose of punishment in the Draft Law of the Criminal Code, and judges' consideration based on the purpose of punishment in Act No. 48 On judicial power?

\section{Research Methods}

To conduct a study in this study the writer uses the sociological juridical method (social legal research) to study and discuss the problems raised. Juridical is an approach that uses principles and legal principles derived from written regulations, sociological is an approach that aims to clarify the real conditions that exist and appear in the community to the problem under study or give importance to the steps of observation.

This research uses descriptive research method. The data used for this study are primary and secondary data. Primary data is data obtained directly from the field or from the first source and has not been processed by other parties. Then secondary data is data obtained from library research consisting of primary legal materials, secondary legal materials and tertiary legal materials. To obtain data in this study, data collection methods are used, namely field research, interviews, and sampling. The data that has been obtained is then analyzed by qualitative analysis.

\section{Results and Discussion}

\subsection{Judge Consideration Policy In Deciding Cases Of Theft Of Crimes Based On Criminal Destinations In The Draft Criminal Code}

In the draft of the Criminal Code Bill, it is found that the provisions On punishment which regulate how the court will determine or impose a crime on the offender is based on the consideration of factors to achieve a proper punishment. Factors in crimes as regulated in Part One relate to the purpose of punishment, the criminal code guidelines and other provisions regarding how the penalties will be applied to the offender. The purpose of criminalization in the Draft Penal Code Act is formulated in Article 54, as follows:

- Prevent criminal acts by upholding legal norms in order to protect the public;

- Promoting the convicted person by holding coaching so that he becomes a good and useful person;

- Resolving conflicts caused by criminal acts, restoring balance, and bringing a sense of peace in society, and

- Freeing guilt on the convict.

In Article 54 paragraph (2) also stated that punishment is not intended to narrate and demean human dignity. According to the Institute for Study and Advocacy of the ELSAM Community, the formulation of the four criminal destinations in the Penal Code draft has views on social defense, rehabilitation and re-socialization of convicts. ${ }^{9}$ This view is reinforced again by stating that punishment is not intended to narrate and demean the dignity that cones on two interests, namely the protection of society and coaching perpetrators.

\footnotetext{
${ }^{9}$ Institute for Policy Research and Advocacy, ELSAM, Position Paper Advocacy for RUU KUHP Series 3 h. 17
} 
Linked to the theory of criminalization, the objectives formulated in the draft text of the Criminal Code Bill above appear to be based on the theory of relative criminalization which has the aim of achieving benefits to protect the community and towards the welfare of society. The purpose of punishment is not retaliation where the sanction is emphasized on its purpose, namely to prevent people from committing a crime. This objective is also in accordance with the utilitarian view as classified by Herbet L.Paker, which is to resolve conflicts caused by criminal acts, restore balance, and bring a sense of peace in society. Thus, the purpose of punishment in the draft concept of the Criminal Code Bill is forward-looking.

The draft of the Criminal Code Bill also recognizes the existence of mitigating conditions inherent in the offender and the objective conditions stated in Article 55 regarding the guidelines for finances. Article 55 of the Criminal Code Bill paragraph (1), in criminal penalties must be considered: Mistake makers of crime; Motive and purpose of committing a crime; The inner attitude of the makers of criminal acts; Is the crime committed by planning; How to commit a crime; The attitude and actions of the maker after committing a crime; Curriculum vitae and socio-economic situation of the criminal perpetrators; Criminal influence on the future of the criminal offender; Influence of criminal acts against the victim or the victim's family; Forgiveness of victims and / or their families; and / or The public's view of the crime committed.

Furthermore, in paragraph (2) it is stated that the lightness of the act, the personal condition of the maker or the condition when the act was committed or what happened next, can be used as a basis for consideration not to impose a criminal act or impose an act by considering aspects of justice and humanity.

Based on the provisions formulated in the concept, it seems that the basis for the implementation of punishment is more inclined to the application of relative theory and leads to integrative theory. This theoretical view suggests the possibility of articulating a criminal theory that integrates several functions as well as utilitarian retribution in which prevention and rehabilitation are all seen as targets to be achieved by a criminal plan. The indications for the foundation of criminal conduct are more inclined to the application of relative theory and lead to the integrative theory as formulated in Article 55 which regulates the consideration of the life and socioeconomic history of the criminal offender, the effect of the criminal on the future, the forgiveness of victims and / or their families,

In addition to the considerations referred to in Article 55, in the explanation of the provisions regarding criminal guidelines, it is also said that the judge can add other considerations with the intention that the sentence imposed is proportional and can be understood by both the public and the convicted person. The judge also has the power to apologize, based on the principle of rechtelijke pardon, someone who is guilty of committing a minor (not serious) crime. This apology was included in the judge's ruling and it must still be stated that the defendant was proven to have committed a criminal offense charged with him.

\subsection{Judges' Considerations Based on Criminal Purposes in Act No. $48 / 2009$ On Judicial Power}

Based on Act No. 48 of 2009 On Judicial Power, the judge in the criminal justice process 
acts as the party that provides for the punishment without ignoring the laws or norms and regulations that live in the community, as regulated in Article 5 of Act No. 48 of 2009 On Power The judiciary which states that Judges and Constitutional Justices are obliged to explore, follow and understand the legal values and a sense of justice that lives and develops in society. Act No. 48 of 2009 On Judicial Power guarantees the freedom of judges in passing verdicts, in addition to having the freedom to determine the type of crime, the size of the criminal or the severity of the crime and how to carry out the crime. The basis of the objective of punishment in the matter of judges' consideration in giving decisions in a trial is also regulated in Act No. 48 of 2009 On Judicial Authority in which the regulated aspects are relevant to the purpose of the punishment. In Article 5 paragraph (1) of Act No. 48 of 2009 explains that "judges and constitutional justices are obliged to explore, follow, and understand the legal values and sense of justice that lives in society". ${ }^{10}$ Exploring, following, and understanding as a form of freedom of judges in considering decisions based on the purpose of punishment is viewed in terms of justice for an accused in providing criminal sanctions.

The basis for non-juridical considerations is the consideration seen from non-legal aspects. The application of the severity of the sentence imposed on a judge is adjusted to the motivations and consequences of the perpetrator's actions, especially in the application of the type of imprisonment, but in the case of certain Laws have normatively regulated certain articles On punishment with minimal threats. The judge in his consideration must also pay attention to the incriminating and mitigating matters as stated in Article 8 paragraph (2) of Act No. 48 Of 2009 On Judicial Power which states that: "In considering the severity, the judge must also pay attention to the nature of good and evil from the defendant ".

Here explained the judge must pay attention to the good and evil nature of the accused, in considering the criminal to be imposed and the personal circumstances of the accused need to be considered or taken into account to provide a criminal that is fair and as fair as possible. The personal situation is obtained from the statements of people from their environment, neighbors, psychiatrists and others. besides that in dropping criminal offenses the judge must delve into the background of the occurrence of the crime by taking into account the nature and seriousness of the crime as well as the circumstances which include the actions that were charged to the defendant, including the level of education, the defendant's personality as well as the environment etc., so that the judge feels confident that the verdict handed down is correct and fair.

Therefore Act No. 48 of 2009 On Judicial Power is relevant to be used as a reference by judges as a basis for judges' consideration in passing verdicts. In practice, judges have the freedom to settle cases they face, are free in this matter as explained previously. Judicial Power is an independent power also is free in examining and adjudicating cases and free from interference from various parties such as government interference and even the superiors of the judges concerned. and even claims filed by public prosecutors.

\section{Closing}

\subsection{Conclusions}

${ }^{10}$ Article 5 paragraph (1) of Law number 48 of 2009 concerning judicial power 
- In Article 54 paragraph (2) also stated that punishment is not intended to narrate and demean human dignity. According to the Institute for Study and Advocacy of the ELSAM Community, the formulation of the four criminal destinations in the Penal Code draft has views on social defense, rehabilitation and re-socialization of convicted people. This view is reinforced again by stating that punishment is not intended to narrate and demean the dignity that cones on two interests, namely the protection of society and the coaching of perpetrators.

- The basis of the objective of punishment in the matter of judges' consideration in giving decisions in a trial is also regulated in Act No. 48 of 2009 On Judicial Authority in which the regulated aspects are relevant to the purpose of the punishment. In Article 5 paragraph (1) of Act No. 48 of 2009 explains that "judges and constitutional justices are obliged to explore, follow, and understand the legal values and sense of justice that lives in society. Article 8 paragraph (2) of Act No. 48 Of 2009 On Judicial Power which states that "in considering the severity, the judge must pay attention to the good and evil nature of the defendant".

\subsection{Suggestions}

- In the current Penal Code, it seems to be rigid and monotonous so that a new Penal Code which is still being formulated is very important because Criminal Law is an Ultimum Remedium, meaning that criminal law should be used as the last remedy or the last step in resolving a problem.

- Criminal imprisonment by judges should not only be formal but must also be "sympathetic" in circles, especially for justice seekers.

- Criminal convictions are often given a prior consideration regarding non-juridical factors, so the judge must be able to understand the conditions that exist in the defendant and also understand the laws that apply in a particular area, because the judge's duty is not only to decide and try cases but also must be able to explore legal values that live in society.

\section{References}

\section{Book}

[1] Chainur Arasjid, 2000, Dasar-Dasar Ilmu Hukum, Jakarta: Sinar Grafika

[2] Satjipto rahrdjo, Perang dibalik Toga Hakim dalam buku: Membedah hukum Progresif, Jakarta: Kompas, 2006

[3] Wirjono Prodjodikoro, Tindak Tindak Pidana Tertentu Di Indonesia, Refika Aditama, Bandung, 2008

\section{Journal}

[1] Haryanto Dwiatmodjo, Penjatuhan Pidana Bersyarat Dalam Kasus Pencurian Kakao, FH Unsoed, Purwokerto, Judicial Journal, Vol.5 No.1, April 2012

\section{Documents}

[1] Research Report, Penerapan dan Penemuan Hukum dalam Putusan Hakim, Jakarta, Secretariat General of the Indonesian Republic's Judicial Commission, 2011

[2] Institute for Policy Research and Advocacy, ELSAM, Position Paper Advocacy for the 
Jurnal Daulat Hukum

Volume 3 Issue 1, March 2020

ISSN: 2614-560X

Criminal Code Bill Series 3 